\title{
K PROBLEMATICE IDENTITY SVËTA (SOCIOLOGIE A FENOMENOLOGIE)
}

IVAN MUCHA

Sociologie vznikla v 19. století jako věda, která si vytkla za cíl odstranit krizový stav tehdejší společnosti. Různé sociologické teorie hledaly jak príčiny tohoto stavu, tak i cesty $\mathrm{k}$ jeho překonání. Sociologie byla od samého počátku vědou o společnosti nacházející se permanentně stavu krize. To platí v jistém smyslu dodnes jak pro dominující teorie systémové (zaměřené na popis chování sociálních mechanismů, v nichž je stav krize jako ohrožení jednoty systému i způsob řš̌ení zakalkulován), ${ }^{1)}$ tak specifickým způsobem i pro fenomenologickou sociologii či pro sociologické teorie inspirované fenomenologii.

Také o současné společnosti plné rozporů a paradoxů můžeme říci, že je ve stavu permanentní krize. Na jedné straně obrovský technickoekonomický rozvoj moderní civilizace a s ním spojený blahobyt $\mathrm{v}$ bohatých zemích dnešního světa a na druhé straně chudoba většiny obyvatel ostatních zemí. V současném světě existují obrovské rozdíly v životní úrovni a životním stylu obyvatel. V moderní sociologické literatuře převládají kritické, skeptické a pesimistické soudy nejen o stavu moderní společnosti, ale také o perspektivách jejího dalšího vývoje. Je to zvlášt' nápadné při srovnávání současného stavu s nadějemi na sociální, národní, politické a jiné emancipace, které byly základem úvah i činů sociálních reformátorů predchozích generací. Mnohé jejich vize byly realizovány, ale s nepředpokládanými důsledky.

\section{Vize smyslu dějin a její zánik}

Optimismus sociálních reformátorů se opiral o ideu jednotného uskutečňování dějinného smyslu, která má svi̊j pi̊vod v teologických eschatologických naukách středověku. Filozoficky nejpropracovaněji byla formulována u Hegela a sociálněpoliticky nejúčinněji působila $\mathrm{v}$ socialistickém hnutí. Předpokladem jejího rozšíření v 19. století bylo reálné zlepšování podmínek života mnoha jedinců i některých sociálních vrstev, které jako by potvrzovalo filozofickoteoretické teze hegelovské filozofie.

$\mathrm{V}$ devatenáctém století, $v$ době formování moderní společnosti, se objevují i úvahy, které tyto optimistické racionalistické vize zpochybňují. Počínaje Nietzschem a Kierkegaardem přes Heideggera až k současným francouzským filozofům²) můžeme

\footnotetext{
1) Systémové teorie zachycuji způsob, jakým jsou krizové momenty eliminovány systémovou diferenciaci Viz N. LUHMANN, OKologische Kommunikation, Opladen 1986, str.214 a n.
} 
sledovat př́mou linii a návaznost. V jejich dílech je zpochybněna idea kontinuity uskutečňování smyslu dějinného vývoje v intencích prozřetelnosti, tedy to, oč se opírala sociální reformační hnutí a co bylo koneckonců i prostým výrazem obecně sdílené důvěry $\mathrm{v}$ lepší budoucnost. Cíl a záměr této kritiky jistě nebyl anarchistický či nihilistický, i když se některé názory těchto autori̊ mnohdy stávaly argumenty nihilistických destruktivních sociálně-politických hnutí.

Rozum, Logos, Vernunft jsou synonyma rádu, uspořádání, harmonie kladené proti neuspořádanosti, chaosu. Protikladení kosmu a chaosu, Boha a d'ábla, dobra a zla je pouze relativizací univerzálního nároku principu rozumu, věčné pravdy, Boha, absolutna. Rozum v koncepci řeckého „Logu“ a "Vernunftu“ německé klasické filozofie je vymezen univerzalisticky. Také lidská zkušenost, prožitky, obraznost podléhají konečnému verdiktu závazného kritéria rozumového soudu. Řecká koncepce filozofie a vědy založená na Logu umožnila specifický rozvoj racionálního myšlení tím, že mezi myšlení, vědomí, rozum a realitu, skutečnost, položila rovnítko, že je v jistém smyslu považovala za identické. Novověká věda tvoří nejvyšší stupeň vývojové řady založené řeckou filozofií. V principu Logu a Vernunftu je obsažen nárok na absolutno. Filozofie a věda usilovaly o univerzální výklad toho, co se děje, uskutečňuje, co je a co platí bezezbytku. Toto výkladové zaměření filozofie hledající neměnný rád univerza proniklo v pokleslé podobě sekularizované představy o smysluplnosti lidského života a dějin do běžného vědomí člověka.

Radikální odmítání představy dějinného smyslu a pokroku můžeme chápat také jako důsledek ztráty významu autorit a tradice způsobené rozvíjením kritického rozumu. Kritický rozum zpochybňuje dogmatizující tendence objektivního rozumu vyjádřené $v$ dobově dominantních institucích a idejích, jejich identitě. S narůstajícím zpochybněním významu objektivních hodnot, národních, sociálních, sociálněpolitických a náboženských ideálů proniká do vědomí člověka a do sociálního života vỉbec pocit osamocenosti, ztracenosti, beznaděje. Reakcí na tuto situaci je i výrazný individualismus a egoismus, který aktivuje ty vlastnosti, které spatřují konečný cíl a smysl života v uspokojování subjektivních potřeb, zájmů a zálib. V oblasti intelektuální se to projevuje množstvím individuálních postojů opírajících se o subjektivně stanovená hodnotová kritéria bez jednotné báze komunikativní korelace.

Jaká je povaha kritického rozumu zaměřeného proti všem podobám transgresovaného rozumu objektivního? Kritický rozum je intersubjektivní a odmítá základy spekulativního, objektivně platného tematizování rozumu ztotožněného s civilizačně působící racionalitou moderních systémů společnosti. Objektivní rozum je rozum nekritický, tematizovaný jako jedině možný výsledek usuzování, směřující k určení identických významů jedinci oktrojovaných. Je to rozum, který má moc, který formuje a sobě podřizuje subjekt, jedince, a to nejen ve smyslu rozumu zákonitostí ekonomických, ale i rozumu zákonů státu či rozumu politického rozhodování podrazujícího všechny individuální námitky jeho autoritě. Kde se bere síla a přesvědčivost tohoto zdůvodnění, když ze zkušenosti víme, že nic nepodléhá tak rychle změnám jako objektivita vědeckého poznání, paradigmata vědecké pravdy? 2) Ze současných francouzských filozofi̊ se tímto tématem zabývaji především J. Derrida a J. Baudrillard.
Hlavní slovo však měli již zemřeli $M$. Foucault a $\mathrm{G}$. Deleuze. 
Intersubjektivita kritického rozumu je proti tomu založena na předpokladu, že identitu významů nelze chápat jako skutečnou, ale spíše jako možnou. Základním požadavkem tedy není jako u objektivního rozumu podřizení se, ale možnost chápat objektivitu komunikovaného smyslu také jinak, než jak ji vnucuji aktualizující př́tomné systémy vědění, prípadně systémy moci. ${ }^{3)}$

Objektivní, neměnné, věčné bylo tradičně ve vztahu $\mathrm{k}$ jedinci tematizováno jako transcendentně metafyzické. $\mathrm{S}$ otřesem metafyziky došlo $\mathrm{i} \mathrm{k}$ otřesu autorit na tomto pojetí závislých a ke ztrátě jejich významu. Objektivita hodnotových předpokladů byla následně zdůvodňována vědeckým myšlením, argumenty poznané pravdy, analogicky pravdám matematickým.

Ztráta tradičních autorit je evidentní. Bezperspektivnost životních orientací, názorová změt' postmodernismu, skepse a hyperkritičnost ke všemu tradovanému je realitou současného sociálního života. Zvlášt' patrné je to v podmínkách takové společnosti, která jedincům umožňuje žít podle jejich individuální, pragmatické životní filozofie, oživované a posilované drobnými úspěchy jako stvrzením její pravdivosti či opravdovosti. Směǒování $\mathrm{k}$ privatizaci života, $\mathrm{k}$ lhostejnosti, skrývající se také za pojmy svobody a tolerance, je vyjádřením dominujícího životního postoje v moderní společnosti, ale také, jak to označují francouzští filozofové, narůstáním barbarismu novopohanství. Tím je myšlena redukce člověka na bytost, jejímž jediným cílem je osobní prospěch, hmotařství nezajímající se o záležitosti veřejné, společné, sociální či politické. Je to utíkání se k životu $\mathrm{v}$ rovině oikos bez ohledu na polis, která se $\mathrm{v}$ moderní době proměňuje ve víceméně dobře fungující systém politické moci, který působí stejnou objektivní a na člověku nezávislou silou jako př́roda. Jako by byla popřena aktivita a úsilí předchozích generací, které usilovaly o vytvoření člověku přiměřeného světa.

Krize rozumu, symptomatická pro dnešní dobu, není krizí technického rozumu, ale je krizí rozumu kulturního, lidského rozumu, humanity, zdravého lidského rozumu, common sense, jakožto rozumu konstruktivního, tvořivého, perspektivního a také rozumu kritického. Moderní doba omezila možnosti jeho působnosti tím, že jej učinila nekompetentním při řešení životně důležitých situací. Místo něj oktrojovala kompetenci rozhodnutí vědeckého rozumu, efektivity, blahobytu, síly, moci. Rešení, která nabízi tento typ rozumu, nedostačují. Jsou zdrojem lidského osamocení, ztráty životni perspektivy, štěstí, naděje. To je rub absence otázky po smyslu dějin.

\section{Fenomenologie a hledání přirozeného světa Lebensweltu}

Na tuto situaci reagovala fenomenologie vyhrocením dualismu otázek, které si na jedné straně klade filozofie a na druhé věda. O metodě vědecké, ve smyslu vykazatelného, evidentního, přesného myšlení se nepochybovalo. Šlo jen o to vymezit kompetenci vědeckého myšleni při řešení otázek, které byly bytostně spjaty, popřipadě formulovány filozofií a opíraly se o životní zkušenost.

3) O kontrolní a regulativní moci systémů věděni jako systémů moci viz M. FOUCAULT, Slova a veci. Archeologia humanitných vied, Bratislava 1987. 
Vývoj fenomenologické filozofie směřval, s ohledem na tematiku jednotného názoru a jednotného smyslu, identity, $\mathrm{k}$ zdůraznění významu světa našeho života (Lebensweltu), předvědeckého světa a jeho jistot jako základu všech dalších tematizací ${ }^{4)}$ Životní svět je tak chápán jako ztracený svět identity, jehož znovunalezení vyžaduje také nový výklad elementárních, podstatných situací sociálních, elementární sociální zkušenosti každého jedince, základní báze veškerého tematizování lidského světa. ${ }^{5)}$ Filozofie a sociologie zde nachází společný prèedmět zájmu a dnes dokonce vzniká dojem, že téma přirozeného světa - Lebensweltu je jedním ze základních témat obou disciplín ovlivněných fenomenologií.

Objevení se pojmu prirozeného světa - Lebensweltu souvisí s krizovou situací moderní doby, se ztrátou životní orientace moderního člověka i s rezignací na přijetí autoritativně předkládaných, oktrojovaných či vnucovaných modelů smyslu jednání v současných společenských systémech. Cesta k nalezení životního světa jako základní skutečnosti lidského života ustavující jeho další významy je především výrazem pokusu o nalezení jistoty životní. Je to pokus o stanovení významů indiferentních k časové proměnlivosti, tedy $\mathrm{v}$ jistém smyslu i pokus o nalezení světa zborcených hodnot metafyzických a transcendentních. Jde zde především o založení jednotného názoru a základu zkušenosti jako vědomého znovuprožití celku skutečnosti.

Životní svět - Lebenswelt je také světem běžných jistot každodenního života, svět reálně platných významů, které určují chování jedinců, jejich myšlení i vưli fundamentálním způsobem. Víme, že tento svět rutinního jednání, skutečných motivů jednání, mechanického vykonávání požadovaných úkonů, přizpůsobení a adaptací je velmi těžko př́stupný, že se skrývá za verbalizovanými, objektivovanými, výkladovými schématy, která jsou výrazem odvolávání se $\mathrm{k}$ autoritám, $\mathrm{k}$ tomu, co je považováno za správné, platné, důležité, tedy $\mathrm{k}$ tomu, co má význam, který přesahuje př́tomné situace i prostor, $v$ němž se jedinec pohybuje.

Fenomenologická filozofie Husserlova staví koncepci životního světa - Lebensweltu transcendentálně fenomenologicky, když Lebenswelt zkoumá ve vztahu. k dějinám a ke krizi rozumu-Vernunft.6) Je zde př́tomna pochybnost o tom, že „co je rozumné je také skutečné“ Hegelovy filosofie. V prirozeném postoji Lebensweltu neplatí, že „,vor der Reflexion kein Praedikat wirklich ist“. Náš první impulz je chápat vše představované $\mathrm{v}$ přirozeném postoji v Lebensweltu bezprostředně jako reálné. Rozlišení fikce a reality , normálního a anormálního je výsledkem racionalizace zakládající se na hlubších vrstvách Lebensweltu, které dosud nebyly explikovány (tedy před Husserlem) a tvoři základ nejen lidské orientace ve světě, ale také toho, co je reálné. Tyto hlubší struktury však nelze objasnit bez přjjetí základních axiomat socializovaného přirozeného postoje, tedy existence inteligentních, vědomím vybavených spolubližních (Mitmenschen), a předpokladu podobné zkušenosti (Erfahrbarkeit) s předměty ži-

4) Kritický rozbor tohoto pojeti Lebensweltu jako ztraceného ráje podává $H$. BLUMMENBERG $\vee$ knize Lebenszeit und Weltzeit, Frankfurt a.M, 1986, v části nazvané Das Lebensweltmissverstandnis, str.7-69.

5) V myšleni francouzského strukturalismu je tento postup zásadním způsobem kritizován a odmítán. Místo od identity vycházejí poststrukturalistické a postmodernistické studie od diference, napřiklad J. DERRIDA. L'écriture et la différence, Paris 1967. K tomu dále M. PETŘ́ǏČK: Úvod do současné filosofie, Praha 1992 a V.DESCOMBES, Stejné a jiné, Praha 1995.

6) E. HUSSERL, Krize evropskych vèd, Praha 1972. 
votního světa mými spolubližními. Lebenswelt je intersubjektivní, je to sociální svět, jak říká A.Schutz „, každodenní životní svět"(alltägliche Lebenswelt)7). Nacházíme se vždy ve světě, který je samozřejmě skutečný a jehož problematizace je teprve výsledkem vědeckého a filozofického myšlení.

Přes všechny pochybnosti, které se dnes objevuji při uvažování o možnostech tematizace Lebensweltu, je třeba zdůraznit jeho nezastupitelnost při analýze základních určení sociálního světa. A není to jen fenomenologie, která se tímto problémem zabývá. Uvažování o Lebensweltu obohatilo bezesporu možnosti sociologické analýzy obecně. Svědči o tom i postupné pronikání tohoto pojmu do sociologického myšlení, které není vyhraněně fenomenologické.

Zájem o Lebenswelt vedl i k obrácení pozornosti ke světu každodennosti, $\mathrm{k}$ popisu základních mechanismů sociální orientace jedinci̊, rutinního jednání, které se o Lebenswelt opírají, nicméně obsah tohoto pojmu nevyčerpává zcela. Mechanizovaná schémata každodenního světa, jednání, myšlení, cítění jsou z hlediska každodennosti funkční, to znamená, že jsou vřazena do předpokládaného horizontu totality, která je nositelem smyslu. Tento horizont tvoří právě Lebenswelt. Použitím kategorií, které obracejí pozornost k podmínkám reálného, konkrétního jednání, se neodkrývají subjektivní představové podněty či motivace jednání. Odkrývá se celý svět, v jehož rámci jsou takové motivace, prèedstavy a projekce jednání teprve možné. Je to svět jiných struktur, než je ten, který analyzují systémové teorie.

Analýza Lebensweltu se mǐže opírat i o pojetí, která jsou mimo pozornost systémových př́stupů, tedy o určité fenomény, které jsou diskontinuitní. Systémové teorie, vědecké teorie $\mathrm{v}$ užším slova smyslu, jako výpovědi o zákonitostech dění předpokládají vždy určitou kontinuitu, která akcentuje významy dominantní. Při rozboru dějinného vývoje jsou tyto akcenty teprve projekcemi interpretace, jimž $\mathrm{v}$ realitě sociální situace, $v$ Lebensweltu určitých období nic reálného neodpovídá nebo to nelze z něj odvodit. Lebenswelt se svým nárokem na totalitu je artikulací zkušenosti světa a života, která ve své komplexnosti zahrnuje jak prvky kontinuity, tj. předpoklady vývoje, evolučních řad, kauzálních souvislostí, tak i diskontinuity, pevných významů petronifikovaných, stálých, neměnných či nově ustavených, které jsou nezbytné $\mathrm{z}$ hlediska funkcionální rovnováhy daného světa. To, co je považováno za nutné, a to, co za nahodilé, je teprve výsledkem racionalizace a interpretací, které již překračuji horizont Lebensweltu. Zkoumání diskontinuit, marginálních problémů, může vést $\mathrm{k}$ odhalení príčin změn v lidském životě i ve světě. Je to předpoklad pochopení napríklad toho, proč určité události mají generativní význam, tedy proč ( $z$ hlediska tradičního schématu výkladu) mohou být považovány za nahodilé a přitom se stávají základem nových zkušeností, nové životní orientace a podstatně ovlivňují myšlení, cítění, jednání. Prostředky $\mathrm{k}$ takovým interpretacím nabízí rozvíjením pojmového aparátu a nových kategoriálních schémat právě fenomenologická sociologie.

Analýza Lebensweltu se opírá o fakt, že základní lidská zkušenost se neděje v poloze individuálně-subjektivního poznání mimo hranice bezprostředních vztahů k dru-

7) A. Schutz v knize A. SCHUTZ, T. LUCKMANN, Strukturen der Lebenswelt, Frankfurt a. M. 1979, část nazvaná Die Lebenswelt des Alltags und die naturliche Einstellung, str. 25-47. 
hým jedincům. Individuální zkušenost je spolupodmíněna zkušeností druhých. Jedinec se pohybuje ve světě spolusdílených a spoluvytvářených významů, ve světě komunikovaného smyslu a intersubjektivity. Odkrytí těchto základních struktur je nenahraditelné, protože bez něj neporozumíme základní intenci lidského porozumění životní situaci. To se netýká jen vztahů $\mathrm{k}$ druhým lidem, ale také $\mathrm{k}$ prírodě a $\mathrm{k}$ dějinám. Rutinní jednání, samožrejmé a nereflektované významy každodenní zkušenosti jsou základem životních jistot, mohou však být vykládány také iluzorně, fiktivně, jestliže zdůrazňují čistě privátní, individuální či parciální skupinové zájmy a významy.Č́m je sociální systém diferencovanější, tím větší a silnější je tendence tohoto falšujicího pars pro toto. Paradoxně jsou tomuto typu nebezpečí více vystaveny moderní diferencované společnosti. Komplikovanost vztahů, značná diferenciace činností, životních stylů, orientací, možností adaptace vede $\mathrm{k}$ zdůrazňování toho, co je $\mathrm{v}$ daném okamžiku utilitární nebo $\mathrm{z}$ hlediska momentálního nároku systému nejefektivnější. Privatizace života jako obrana proti tlaku systému je umožněna právě ve vyspělé společnosti, která materiální nezávislost a intelektuální samostatnost privatizace života dovedla na nejvyšší stupeň ve smyslu nabízené, institucionálně zajištěné soběstačnosti, systémově zakalkulované. Moderní společenské systémy, které vykonávají na jedince obrovský tlak, z něj dělají manipulovatelný element systému, silně atakují svět každodennosti a zakrývají nebo mají tendenci zakrývat podstatné dimenze toho, co přes veškerý tlak systému nese svět každodennosti, tedy lidský rozměr přrozeného postoje Lebensweltu. Nabízená možnost úniku do privátní sféry je pǔ́mo systémem způsobema, ale na ní postavená identita lidského života a světa je fiktivní.

\section{Jistota a pravdivost Lebensweltu}

Nyní si můžeme položit otázku, co je základem jistoty a pravdivosti, hodnotového významu Lebensweltu, která tvoř́ širší rámec jistot každodenního jednání. Je jasné, že povaha této jistoty není ontologicky zakotvena ve smyslu starší metafyziky. Dnes se často spatřuje príčina současné krize společnosti právě v absenci takového principu, lapidárně řečeno $\mathrm{v}$ absenci Boha. Zůstaneme-li však u předpokladu Lebensweltu jako základní jednotné roviny lidského vztahování ke světu předmětů, věcí a osob, pak je zde tato otázka položena radikálně novým způsobem. Jestliže se určité odpovědi vyčerpaly, přestaly platit, ztratily svou funkci a zanikly, neznamená to ještě, že nebudou hledány nové.

Zodpovězení základních otázek po smyslu bytí nemůže být nikdy definitivní ani jednotně akceptované. Je ale zaměřeno právě $\mathrm{k}$ této předpokládané jednotě, $\mathrm{k}$ možnosti nalezení univerzální jistoty. Racionalistická filozofie ji hledala a domnívala se, že ji nalezla, $v$ modelu vědeckofilozofického myšlení novověku jako jediné skutečně závazné autority a měřítka všech významů. Že je to řešení iluzorní, o tom svědčí krize moderní společnosti, znejistění světa, rozbití tradičních hodnotových systémů, rozbujelý relativismus a pragmatismus egoistických postojů, $v$ nichž se projevuje absence Boha a ztráta legitimity.

Aplikace pojmu Lebenswelt může také změnit sociologické výklady morálky, autority a tradice. Morálka je sociologicky pojímána jako reálně fungující sociální systém, 
který reguluje a kontroluje sociální vztahy. Zdůrazněním obecně-funkcionálního významu je dána možnost srovnávání různých morálek, podobností a odlišností jejich obsahu $v$ jednotlivých společnostech. Je to vlastně popis mechanismů funkcí a činností, jejich diferenciace formální i obsahové, který nejobsáhleji zachycují teorie strukturalistické a systémové. V duchu evropské tradice si však nemůžeme odpustit otázku, co je základem konstituce, ustavení systémů morálky a předpokladem jejich trvání i změn. Především proto, že v dějinách evropského myšlení byly základní principy morálky konstituovány fundamentálním způsobem přnejmenším třikrát. V modelu antickořeckém, křest’anskostředověkém a novověkovědeckém.

Autorita rozumu měla vystřídat autoritu tradice přinejmenším od osvícenství. Osvícenství pouze důsledně formulovalo a rozvijelo tendenci, která je trvale prítomná $\mathrm{v}$ evropských dějinách a vychází z podstatného určení člověka jako rozumné bytosti. Základní problém stále spočívá v určení tohoto rozumu. To se pohybuje ve dvou krajních polohách. Jednou z nich je ta, která dřive zajímala křest’anskou dogmatiku i antickou koncepci světa idejí, tedy ontologicko-metafyzickou teorii o jistotě myšlení, racionálním výkladu světa neměnných hodnot a autorit, podstat, bytí, toho, co jest. Druhá poloha je v neustálém racionálním zpochybňování odpovědí na otázku, co je podstatou bytí, či otázky po podstatě bytí samé. Jestliže intence prvního směřování byla od rozumu $\mathrm{k}$ tradici, pak druhá je od tradice $\mathrm{k}$ rozumu. Toto napětí je prirozené a je napětím, které je vlastní i Lebensweltu, ale které jako by zmizelo a nebylo dále reflektováno v současné vědě společenské, ani ve filozofii. Rozum v modelu novověké vědeckotechnické civilizace hypertrofuje i v systémových teoriích do popisu změn, dění, vývoje jako nutného samopohybu, kde tradice má jen funkcionální, a nikoliv fundamentální význam. ${ }^{8)}$ Podobně jako všechny normativní a hodnotové systémy.

Z tohoto hlediska můžeme ř́ci, že ztrátu životních jistot do značné míry způsobuje právě rozvoj tohoto typu racionality. Spíše nežli zkušenost, individuálně závazné, zodpovědnost, životní horizont prožívání a podobněji zajímá samovývoj systému, tedy systémová racionalita, popis vývoje moderní společnosti v kategoriích, které se vyznačují instrumentálně operativními postupy a které redukují svět člověka na prostor závaznosti mechanicky založené.

$\mathrm{K}$ povaze tradice patři to, že je transcendentní, tedy svou povahou přesahuje aktuální podobu toho, co je považováno za významné a co je součástí komunikovaného smyslu v současné interakci. Moderní společnost transcenduje významy technickovědecké civilizace a to, co je tradiční v pưvodním slova smyslu a patři do transcendentní roviny očekávání, naděje, komunikuje $\mathrm{v}$ redukovaných významech momentální účelovosti a efektivity. Tím je porušeno napětí mezi přirozenými postoji Lebensweltu a orientací ve světě podle aktuálních požadavků toho, co trvá, a toho, co se mění.

Integrita společnosti však nemůže být budována jen na schématech běžné komunikace a interakce. Taková tematizace problematiky sociální interdependence, která pronikla do sociologie posledních let a měla velký význam při výkladu jevů moderní spo-

\footnotetext{
8) To se týká především pojetí autopoietických systémů. Základním způsobem je tento postup již naznačen v práci N. LUHMANN, Soziale Systeme, Frankfurt a.M. 1984, v části Selbstreferenz und Rationalitat, str. 593-647.
} 
lečnosti, vedla svojí utilitárností i $\mathrm{k}$ vyprázdnění časového horizontu minulosti a s tím spojené absenci historického pohledu při analýze konkrétní společnosti. Každé konkrétní společenství má své časové horizonty, jejichž popis předpokládá i sebrání značného množství konkrétních fakt a údajů. Všímá si situací jednání, jejich okolností, možných kauzálních souvislostí, které nemůžeme bez zkreslení zachytit v systémové teorii, ale musíme vykládat v interpretacích možné zkušenosti. Lebenswelt je světem faktické konkrétnosti, ve kterém se prolíná to, co je komunikováno, intersubjektivní $s$ tradovaným. Jednota zkušenosti není založena na komunikovaném smyslu, ale spíše na prriblížení se, na shodě či odklonu od tradovaného smyslu. Ten není kladen jako samozřejmý, ale musí být stále hledán, odkrýván, argumentován. Př́klon k reduktivním teoriim smyslu systémového typu vede často $\mathrm{k}$ akcentování iluzorních jistot či identit, které jsou výsledkem pouhého popisu daného pohybu či mechanismu sociálního celku a vlastního jádra identity se nedoberou.

\section{Nazření a ideace sociální skutečnosti}

Fenomenologická sociologie $\mathrm{v}$ protikladu $\mathrm{k}$ tradiční sociologii zakládá identitu společenství, prožívání a jednání na tom, co je názorné. To je př́pad jak starší fenomenologie dvacátých a třicátých let, tak i fenomenologie současné. Je to předpoklad trvání základních, podstatných určení životních a sociálních situací, které tvoří základ každého společenství. Jejich deskripce fenomenologická je tak zároveň nazřením fundamentální roviny, ze které se pozvedají ideační konstrukce reálného sociálního světa. Realita moderní společnosti je zachycována vědeckou, ideační činností.

Popis sociálního organismu společnosti se tedy děje v ideacích opírajících se o to, co je názorné. Důraz na názorné, fundamentální či podstatné bývá v jiných sociologických teoriích často zaměňován za významy fungování v kontextu prakticko-operacionálního, technického, ideologickopolitického či jiného modelu dobově dominantního. Tento zájem o ontické, prezentovaný v pluralitě sociologických př́stupů, je však také důvodem diferenciace výkladových postupů sociální skutečnosti a nese s sebou ztrátu sociální a životní identity. Heideggerovo zjištění o nadvládě onoho, das Man, zapomenutosti bytí je v sociologii možno chápat jako zapomenutí názornosti fundamentálních významů lidského soužití. Akcentování ideační činnosti vědecké teorie, nové racionality rozvíjené novověkou vědou, vede také $\mathrm{k}$ zastření prožívání významu skutečnosti $\mathrm{v}$ její konkrétní názornosti jako jednoho ze základních určení životní orientace.

Při kritice fenomenologické sociologie dochází často $\mathrm{k}$ mylnému závěru, že určení identického názoru ve fenomenologii znamená zároveň určení identity smyslu. Je sice pravda, že identické nažrení může být základem identického smyslu, ale identický smysl se nemusí vždy opírat o identický názor. Je to především proto, že zatímco názor má význam mezní, stále př́tomný, jasný, neartikulovaný, je smysl vždy výsledkem artikulace, ve které se uplatňuje interpretace, argumentační mnohovrstevnost a také diferenciace východisek. Bez vztahu k názornému, jasnému, evidentnímu je rozum hypertrofován a ve své expanzivní schopnosti, sebevymezování, sebereference, sebeurčování přesahuje hranice zkušenosti ve fundamentálním filozofickém významu, 
a opouští tak oblast přirozeného, naivního, žitého smyslu. Identita smyslu rozumových konstrukcí se pozvedá nad, ale také mimo svět žitých významů Lebensweltu. Identita smyslu $\mathrm{v}$ tomto kontextu může také být založena na něčem, co není identitou názoru, což je jedním ze znaků moderní civilizace, která v moderních sociálních systémech vnucuje jedinci prostřednictvím institucionálně mocenských autorit vzorce chování, myšlení, jednání, prožívání, životní orientace. Otázka názorové identity ve fenomenologickém smyslu není vůbec položena, stejně tak jako se nebere v úvahu význam rozumu a zkušenosti v kontextu žitého života. Subjektivní, privátní, individuální je tak posunuto do oblasti nepodstatného, náhodného, kontingentního.

Názorová identita ve schématech fenomenologické sociologie byla tematizována zpočátku pod vlivem Husserlova určení názoru jako podstatného předpokladu evidence základních pojmů logiky, matematiky, prírodních věd, jazyka vůbec. Názorová identita kategorií a pojmů však není zcela totožná s názorovou jednotou regionu sociální skutečnosti, který nás zajímá. Velké téma fenomenologické sociologie je konstituce světa, tedy vlastně pokus o založení jednotného názoru, který je zároveň předpokladem možnosti porozumění sociální skutečnosti.

Hlavní otázkou pak je, na čem se zakládají autority tohoto jednotného názoru a zda nám zde postačí typ konstituce opírající se o autentické nazření a jistoty analogické nazíranému regionu čísel, pojmů, kategorií vědeckého myšlení, významů, které jsou mimočasové. Jistoty a evidence logicko-epistemologické mají obecný význam pro jazyk vědy, ale z hlediska sociálního světa a sociálních věd tvoři pouze skelet. Musíme počítat ještě $s$ jinou názorovou bází evidence sociální skutečnosti, která vyrůstá z tradice. Evidence jistoty tohoto typu se musí opírat o analýzu nejen názorové identity, ale také identity tradice. Znamená to také výrazný posun v tradičním fenomenologickém pojetí tohoto problému oživením zájmu o obrazné a symbolické, které hraje v názoru značnou roli.

\section{Identita kulturní tradice}

Stanovením Lebensweltu - přirozeného světa - za východisko úvah o identitě je reflexe odsunuta poněkud stranou. Lebenswelt je svět předreflexivní a fenomenologické analýzy poukazují k tomu, že reflexe nemá základní životní význam. Kritika racionalismu idealistické filozofie, základním způsobem formulovaná Nietzschem, zaměřila pozornost $\mathrm{k}$ hledání jiných jistot a pravd, než jsou pravdy rozumu. Filozofický idealismus, logocentrismus, ${ }^{9}$ je dnes považován i za zdroj iluzorních schémat falešně prédjímajících světový vývoj, který ve své důvěře ve věčné pravdy, neustálým poměřováním reálného ideálním ztratil smysl pro prítomné, a tím deformoval obraz skutečnosti.

Logocentrismus však může znamenat jen snahu po syntetickém rozumovém uchopení celku světa, jeho vývoje, proměn v co nejobecnějších pojmech. Takovému pokusu musíme přiznat jeho právo, vždyt' to bylo konečným úsilím filozofie od jejího po-

\footnotetext{
9) Kritika logocentrismu a jeho odmítáni je jedním z hlavních témat francouzské poststrukturalistické filo-
} zofie, hlavně u M. Foucaulta a J. Derridy. 
čátku. Tyto syntetizující pokusy byly také předpokladem jednotného pojímání evropské kultury, jejího úsilí po sebepochopení, o porozumění minulosti a plánování budoucnosti. Je však také pravda, že tyto schematické syntetizující výklady se často stávaly zdůvodněním vzniku institucí s výrazně represivní funkcí. Kontinuita tradice byla chápána jako kontinuita postupné realizace hodnot $\mathrm{v}$ minulosti založených $\mathrm{a} \mathrm{v}$ budoucnu realizovatelných. Př́tomnost jako to, co je přechodné, momentální, nepodstatné a profánní, byla diskreditována s ohledem na význam závaznosti minulosti a nadějí promítaných do budoucnosti.

Ve Foucaultově pojetí je kultura určena diskurzem, který jedince vězní a předepisuje mu, jak má myslet a jednat. ${ }^{10)}$ Identita kulturní tradice nevyri̊stá z vnitřní logiky diskurzu, ale je kontrolována, regulována, selektována, organizována a kanalizována a to tak, aby všechny nevypočitatelné události byly eliminovány. Zvlášt' v moderních společnostech je tlak systému dirigujícího diskurs tak mocný, že téměř eliminuje možnosti odporu skupinového či individuálního a nutí členy společnosti k rezignaci. Tradice se mění $v$ př́tomnosti $v$ derivační nástroj moci aktualizací časných požadavků funkcionálně nezbytných $\mathrm{z}$ hlediska stávajících struktur. Vše je tedy směřováno $\mathrm{k}$ posílení falešné identity mocenského nástroje systému.

Světonázor vědy je založen na předpokladu objektivně platných významů, na akceptování struktur myšlení, které mají analogie ve strukturách moci a jejichž autorita se může dokonce stát i zdůrazněním autority moci. To se projevuje nejen absencí určitých kategorií a pojmů $v$ těchto teoriích, ale i $\mathrm{v}$ jejich celkovém zaměření, které preferencí pojmu funkce zvažuje pouze ty souvislosti vztahů, které jsou ve své obecnosti výsledkem formalizací.

Pojetí identity kulturní tradice musí vycházet $\mathrm{z}$ bezprostřední zkušenosti jednajícího a může být budováno na jiném základu než je diskurz v rámci epistém. Zkušenost, kterou mám s druhými, je výsledkem neustálé konfrontace mého světa s jejich světy. Promítá se do ní především základní konstitutivní prvek formující mé životní postoje v socializačním procesu. Bez artikulace této skutečnosti mi uniká základ proživání jednoty sociálního života komunit. Spíše nežli na normách kontrolujících a regulujících chování, se zakládá na širši bázi představové imaginace a její metaforické podobě. Vztah, postoj k druhému je zde otevřený, postoj, kdy jsem ochoten porozumět orientacím druhého, především s ohledem na úspěšnost vlastního jednání. $Z$ toho také vychází typizace postojů, které jsou důležité v konstituci sociálního světa a jeho porozumění.

Systémové teorie nemohou proniknout do roviny individuální a sociální zkušenosti jedince. Zkušenost je vždy zkušeností o skutečném, o něčem jsoucím v nejširším smyslu; at' je toto jsoucí subjektivní či objektivní, reálné či ideální, dáno originálně či způsobem zprostředkovaným. Od toho, co se nám ve zkušenosti ukazuje je třeba přejít ke strukturám, kterými je svět (či ve starší tradici transcendentálno či transcendentální subjektivita) vymezen. ${ }^{11)}$

Tím je vlastně položena otázka, zda lze zcela opustit tematizaci toho, co je metafyzické a transcendentální. V otázce identity to zřejmě nebude možné, nebot' položme-

10) M. FOUCAULT, Diskurz, autor, genealogie, Praha 1994.

11) A. SCHUTZ, Theorie der Lebensformen, Frankfurt a. M., 1981. 
-li si otázku po celku a jeho identitě, pak se nevyhneme znovupromýšlení závaznosti témat kladených v tradici metafyzické a transcendentální filozofie. Metafyzika je př́tom možná pouze jako vědomí znovuprožití celku skutečnosti. Metafyzika v transcendentálním idealismu není naukou o transcendentně jsoucím samém o sobě, nýbrž je to nauka o jsoucnu jako takovém, tedy nauka o konstituci. Spolu s tím je třeba vzít v úvahu, že jednotnou bází, na které se to děje, je svět, který se ohlašuje v celé řadě konkrétních fenoménů. Náš svět je konkrétním světem životního společenství, $\mathrm{k}$ němuž přináležíme. Je něčím relativně konstantním a jeho změny se nedají přímo kontrolovat jako změny jednotlivých věcí. Změny v našem světě se odbývaji netematicky, bez naší vědomé spolupráce a teprve pohled reflexe je s to je v upomínce zachytit, pojmout.

To, co nazýváme fiktivní identitou, je základem světonázoni společností moderní civilizace. Záměrně používáme označení světonázorů s ohledem na význam, který tomuto pojmu dával Dilthey, tedy jako souhrnnému, jednotícímu názonu na svět, který je funkční z hlediska života. Je to jedna z životních funkcí lidského rodu, diferencovaná podle společenství, času a místa, historické zkušenosti, politických činností a podobně. Světonázor má v sobě vždy také prvky ideologie, zde ve smyslu určitého idolu, falešného obrazu redukujícího mnohovrstevnost bytí $\mathrm{z}$ hlediska životně, tedy sociálně, politicky, ekonomicky, a biologicky nutných funkcí. Všechny dobově převládající ismy, pozitivismus, naturalismus, biologismus, sociologismus a další jsou jen rỉznými variantami tohoto redukcionismu světonázorového. V moderních systémových teoriích, v obecné teorii systému, v jejím užití v biologii, kybernetice i sociologii má tento redukcionalismus nejpregnantnější podobu. Jeho rozšiření, uplatnění a bezesporu i efektivita popisu rozmanitých jevi̊ je dáno také změnou životní orientace, životního stylu, di̊sledkem jevu reifikace světa.

Proti fiktivní identitě, vyjádřené $\mathrm{v}$ sociálně integrativním požadavku moderních systémů společnosti, která je výrazem koordinace úkonů reifikovaného světa, světa zvěcnělých vztahů, vnějšího regulátoru činností, je skutečná identita skryta $v$ tradici konkrétních společenství. Tato tradice však nemůže být prezentována v systémové teorii jako to, co je vnější a co má ideologickou a světonázorovou funkci. Všechny podobné pokusy ztroskotávají a jsou následně doprovázeny procesem rozpadu hodnot. Proces rozpadu hodnot není ničím jiným, než popisem zániku zvnějšnělých forem hodnotových a normativních systémů a jejich ideologicky a světonázorově přeceňovaného významu. Tradice se nedá manipulovat, operacionalizovat, nelze ji institucionálně vnucovat.

Tradované významy se nenabízejí samy o sobě, ale vybízejí k novým interpretacím, novým artikulacím obrážejícím novou zkušenost času. Fenomenologická sociologie svým zaměřením stojí dnes nejblíže objasnění konstitutivních prvků života společenství, které v okamžiku ohrožení aktivuje síly své národní, etnické, sociální, životní identity. Ta vyrůstá $z$ tradice. Právě v okamžiku ohrožení, což je zkušenost především malých národů, které $\mathrm{v}$ nevýhodných geografických podmínkách čelí převaze národů velkých, pozvedá se intenzivně snaha po určení národní identity, která se jistě neobejde bez mylných a falešných interpretací. Veškeré civilizační i technické vymoženosti nemohou nahradit nebezpečí ztráty národní či etnické identity. To, že moderní socio- 
logie je př́liš stržena abstraktními schématy výkladu obecných zákonitostí vývoje, promýšlením exaktních teoretických schémat a metodologických př́stupů, není ještě zárukou její skutečné úspěšnosti. Odhlížením od žité tradice společenství ztrácí možnost pochopit, porozumět jedinečnosti konkrétních změn, k nimž dochází. Vize civilizačního technického pokroku, opírající se o schémata dosud efektivních koncepcí jeho prosazování, nevěnují pozornost složitému procesu, který je základem života každého společenství a na který poukázala poprvé ve filozofii koncepce přirozeného světa Lebensweltu.

Nalezení reálné identity je iluzorní. Jde spiše o její hledání. Záměna, která je podána $v$ reduktivním kroku stanovení fiktivní identity, která funguje jako konečná, funkcionálně nezbytná, je zavádějící. Jediná možná cesta je hledání reálné identity, tedy neustálé přesahování, transcendování toho, co je funkcionálně považováno za nezbytné a nutné. Tendence $\mathrm{k}$ banalizaci života je vlastně výrazem rezignace na hledání identity tradice. Je to proces, který Heidegger nazývá útěkem myšlení k systémům mínění.

Jestliže fenomenologie vystoupila s programovým heslem návratu $\mathrm{k}$ věcem, který byl pokusem vymanit se $\mathrm{z}$ labyrintu různých gnozeologických př́stupů $\mathrm{k}$ výkladu skutečnosti, pak reifikace světa podaná ve strukturalistických a systémových teoriích (i těch, které jsou inspirovány fenomenologií) tento požadavek nesplňuje. Jestliže dnes tyto teorie podávají nejpřesvědčivější výklad chování sociálních mechanismů, pak je třeba si stále uvědomovat, že se to děje v mezích těchto teorii samých, v popisech redukujicích zkušenost, racionalitu způsobem omezujícím se na popis a rezignujícím na porozumění. Návrat $\mathrm{k}$ věcem nebyl míněn jako reifikace světa. Znamená také návrat $k$ věcnosti ve smyslu konkrétnosti, faktické a věcné přesnosti, $s$ ohledem na tradici, vymanění se $z$ ideologicko-světonázorových klišé a frází. Cesta $z$ tohoto zakletí vede přes porozumění reálné identitě tradice a na ní založené identity životní a sociální orientace.

\section{On the Problem of the Identity of the World}

\section{Sum mary}

The theme of the article is the description of the two differing conceptions of the rationality and identity of the world, thought and reality represented on the one hand in system theories and on the other in phenomenologically orientated sociology. System theories describe processes of modernization in contemporary society as matters of the assertion and application of systemic rationality, while phenomenology is mainly interested in the rationality of everyday action and of natural attitudes in the Lebenswelt. A thorough thinking through of the problem of Lebenswelt leads to the return of questions of the meaning of human action, and the continuity of the development of communities and solidarities, traditions etc. Without such an approach, it is impossible to understand social reality even in an environment where systemic rationality is being aggressively applied. 